УДК: 658.07

\title{
ОСОБЛИВОСТІ ФОРМУВАННЯ ФІНАНСОВОЇ СТРАТЕГІЇ ПІДПРИЕМСТВ ЗАЛІЗНИЧНОГО ТРАНСПОРТУ
}

\author{
Карачарова К.А., к.е.н, доцент (УкрДУЗТ)
}

У статті визначено, щуо стратегічне управління фінансами підприємств дає можливість ефективно управляти грошовими потоками, капіталом та інвестиціями. Відправною точкою формування фінансової стратегії підприємств залізничного транспорту має стати діагностика фінансової діяльності $i$, перш за все, діагностика фінансового забезпечення підприємства. Для діагностики фінансового забезпечення підприємств залізничного транспорту запропоновано три базових критеріі оиінки стану фінансових ресурсів підприємства. На базі значень циих трьох критеріїв визначається інтегральна оцінка, яка характеризує якість фінансового забезпечення $і$ є підставою для прийняття відповідного стратегічного рімення.

Ключові слова: фінанси підприємства, фінансове забезпечення, фінансова діагностика, фінансова стратегія, підприсмства залізничного транспорту.

\section{ОСОБЕННОСТИ ФОРМИРОВАНИЯ ФИНАНСОВОЙ СТРАТЕГИИ ПРЕДПРИЯТИЙ ЖЕЛЕЗНОДОРОЖНОГО ТРАНСПОРТА}

\section{Карачарова К.А., к.э.н, доцент (УкрГУЖТ)}

В статье определено, что стратегическое управление финансами предприятий дает возможность эффективно управлять денежными потоками, капиталом $и$ инвестициями. Отправной точкой формирования финансовой стратегии предприятий железнодорожного транспорта должна стать диагностика финансовой деятельности и, прежде всего, диагностика финансового обеспечения предприятия. Для диагностики финансового обеспечения предприятий железнодорожного транспорта предложено три базовых критерия оценки состояния финансовых ресурсов предприятия. На основе значений этих трех критериев определяется интегральная оченка, которая характеризует качество финансового обеспечения и является основанием для принятия соответствующего стратегического решения.

Ключевые слова: финансы предприятия, финансовое обеспечение, финансовая диагностика, финансовая стратегия, предприятия железнодорожного транспорта

\section{FEATURES OF FORMATION OF FINANCIAL STRATEGY OF ENTERPRISES OF RAILWAY TRANSPORT}

\section{Karacharova K. A., candidate of economic sciences, associate professor (USU of RT)}

The article identifies that the strategic financial management of railway companies allows you to efficiently manage your cash flows, capital and investment. Proven financial strategy should be based on the preferred management corporate and competitive strategies, to ensure their performance and, in turn, is the basis for the effective formation of corporate and competitive strategies. The starting point of formation of financial strategy of the enterprises of a railway transportation should become diagnostics of financial activity and, first of all, diagnostics of financial security of enterprise. For diagnostics of the financial providing of enterprises of railway transport proposed three basic criteria of assessment of the status of financial resources of the enterprise. Based on the values of 
these three criteria is determined by the integrated assessment, which characterizes the quality of financial security and is a basis for making appropriate strategic decisions.

Keywords: finance company, financial security, financial diagnosis, financial strategy, enterprises of rail transport

Постановка проблеми та ї̈ зв'язки 3 науковими чи практичними завданнями. Ефективність функціонування підприємств залізничного транспорту в умовах нестабільного, а деколи й агресивного зовнішнього середовища, значною мірою обумовлюється обраною стратегією їх розвитку. Однак визначення стратегічних перспектив в сучасних умовах господарювання більшою мірою носить інтуїтивний характер з орієнтацією на поточну ринкову кон'юнктуру, а не на власні довгострокові економічні інтереси. При цьому планування зачіпає в основному експлуатаційну сферу i здійснюється епізодично по мірі необхідності ліквідації виникаючих внутрішніх і зовнішніх проблем. Аналіз i розробка фінансових стратегій керівництвом підприємств залізничного транспорту, як правило, не практикується через велику диверсифікованість діяльності ПАТ «Українська залізниця» та, відповідно, складністю і трудомісткістю самого процесу формування фінансової стратегії.

В той час, як стратегічне управління фінансами дає можливість провести оптимізацію фінансових результатів діяльності підприємства, підвищивши іiі фінансову стійкість і ліквідність, а також ефективного управління грошовими потоками, капіталом та інвестиціями, що особливо важливо в сучасних реаліях функціонування підприємств залізничного транспорту.

Аналіз останніх досліджень $\boldsymbol{i}$ публікацій. На сьогодні тема дослідження теоретичних основ розвитку та управління залізничним транспортом України досить популярна, ій присвячена ціла низка праць за авторством: В.Л.Диканя [1], М. Макаренко, М. Цвєтова [2], О.О. Коковіхіна [3], Д.І. Бойко, Н.Ю. Шинкарьова [4] та ін.

Концептуальні аспекти стратегічного управління представлені в працях O.C. Виханського [5], И.Ансоффа [6], Б.М. Шифріна [7], В.Л. Диканя, В.О. Зубенко, О.В. Маковоз, І.В.Токмакової, О.В. Шраменко [8] та ін.
Виділення невирішених частин загальної проблеми. Аналіз теоретичних напрацювань із зазначеної проблематики свідчить про високу зацікавленість вітчизняних та закордонних вчених. Разом 3 тим явно необхідні нові дієві пропозиції, що дозволять добитися високих економічних результатів в проблемі формування фінансової стратегії підприємств залізничного транспорту.

Мета стратегії підприємств залізничного транспорту.

Основний матеріал. Стратегією підприємства є генеральна програма розвитку, яка визначає найголовніші пріоритети стратегічних завдань, способи залучення i розподілу ресурсів, послідовність кроків по досягненню стратегічних цілей і найбільшою мірою відповідає ситуації, що склалася, як у внутрішньому, так і у зовнішньому середовищі. Основна задача стратегії полягає в тому, щоб виконавши певний алгоритм дій, трансформувати даний стан підприємства в бажаний для керівництва i власників майбутній стан [9, с. 236].

Фінансова стратегія $\epsilon$ одним 3 основних видів функціональної стратегії підприємства, що забезпечує всі найголовніші напрями розвитку його фінансової діяльності, a також фінансових відносин шляхом розробки фінансових цілей на довгострокову перспективу, вибору оптимальних шляхів їх досягнення, поточної коригування напрямків формування та використання фінансових ресурсів у разі зміні "правил гри" у зовнішній середовищі.

Іншими словами, це комплекс заходів, спрямованих на досягнення перспективних фінансових цілей [10, с. 36].

Необхідність виділення особливого місця фінансової стратегії у процесі створенні загальної стратегії підприємств залізничного транспорту визначається:

- диверсифікацією сфер діяльності ПАТ «Українська залізниця» в плані 
охоплення ним різних ринків, у тому числі й фінансових;

- необхідністю постійного пошуку джерел фінансування великої кількості стратегічних проектів;

- присутністю загальною для всіх корпорацій кінцевої цілі при виборі таких стратегічних орієнтирів, як максимізація ефекту від фінансової діяльності;

- динамічним розвитком як міжнародних, так і внутрішніх (національних) фінансових ринків.

Таким чином, фінансова стратегія повинна базуватись на обраних керівництвом корпоративній та конкурентній стратегіях, забезпечувати їх виконання та, в свою чергу, фінансова стратегія $€$ основною для ефективного формування корпоративної та конкурентної стратегій.

Відправною точкою формування фінансової стратегії підприємств залізничного транспорту має стати діагностика фінансової діяльності i, перш за все, діагностика фінансового забезпечення підприємства, оскільки від ефективності цього процесу залежить вся подальша виробничогосподарська діяльність. Нестача фінансових ресурсів може практично повністю паралізувати всю діяльність суб'єкта господарювання, що зумовлює необхідність постійного моніторингу, діагностики фінансового забезпечення та відповідного корегування стратегічних орієнтирів.

Для діагностики фінансового забезпечення підприємств залізничного транспорту запропоновано три базових критерії оцінки стану фінансових ресурсів підприємства:

1. Відповідність структури капіталу активам підприємства - класифікація за даним критерієм побудована, виходячи 3 того, що 3 першої до четвертої групи суттєво збільшується ризик та знижується ефективність структури капіталу підприємства. Кожній 3 груп за критерієм структури капіталу відповідає певна характеристика, яка $\epsilon$ досить узагальненою, але дає змогу оцінити ситуацію, що склалася на підприємстві стосовно його структури капіталу. Це показники: коефіцієнт автономії

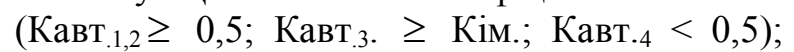
коефіцієнт іммобілізації активів (Кім $1,2,3 \leq$ Кавт; Kiм $_{4}>$ Кавт); коефіцієнт короткострокової заборгованості (Кк3 $3_{1}<0,4$; $\mathrm{K \kappa}_{2} \leq 0,4 ; \mathrm{K \kappa}_{3,4}>0,4 ;$ ).

2. Структура поточного фінансування рівень фінансового забезпечення поточної господарської діяльності. Ситуації, що в процесі діагностики мають бути віднесені до однієї з чотирьох груп, мають задовольняти вимогам систем рівнянь для кожної групи. Обрані показники доцільно використовувати для загальної діагностики. Це показники: власний оборотний капітал $\left(\mathrm{BOK}_{1,2}>0 ; \mathrm{BOK}_{3}\right.$ $\geq 0 ;$ ВOK $_{4}<0$ ); коефіцієнт забезпеченості власним оборотним капіталом (Кзаб. $\geq 0,4$;

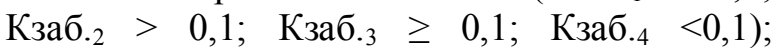
коефіцієнт забезпеченості власними коштами запасів і витрат $\left(\mathrm{K}_{33_{1}} \geq 0,6 ; \mathrm{K}_{33_{2}} \geq 0,2 ; \mathrm{K}_{33_{3,4}}<\right.$ 0,2); період обертання кредиторської і дебіторської заборгованостей відповідно (ПОк $3_{1,2,3}>$ ПОд $3_{1,2,3} ;$ ПОк $3_{4}<$ ПОд $\left.3_{4}\right)$.

3. Структура внутрішніх резервів та фінансових результатів підприємства підприємство на різних етапах свого розвитку може мати не завжди тільки позитивні фінансові результати, і тут важливо виявити, чи $є$ така ситуація випадковою, чи це вже стало шляхом підприємства до майбутньої кризи. Це показники: прибуток (Пр =1, Пр =0 - наявність або відсутність прибутку відповідно); рентабельність $\left(\mathrm{P}^{\phi}, \mathrm{P}^{\Pi}\right.$ фактична та планова відповідно); середня ставка проценту за банківськими кредитами (Б $)_{\text {к }}$; коефіцієнт зростання доходу і майна (Кд, Км); наявність або відсутність прибутку у підприємства у минулих звітних періодах (Пм.р. = 1; Пм.р. = 0); збитки підприємства фактичні (3б $)$; граничний розмір збитку, який підприємство припускає на даному етапі розвитку (3б гр).

На базі значень цих трьох критеріїв визначається інтегральна оцінка (рис.1), яка характеризує якість фінансового забезпечення i $\epsilon$ підставою для прийняття відповідного стратегічного рішення.

Таким чином, групу I можна вважати як таку, що позитивно характеризує фінансово-господарську ситуацію на підприємстві i не потребує перегляду фінансової стратегії та суттєвого управлінського втручання. Група II - це місце ризику фінансових результатів, i без перегляду існуючої фінансової стратегії підприємство може зсунутися в бік найбільш ризикованої групи. Група III включає до свого 
Коковіхіна. - Вісник економіки транспорту i промисловості: збірник науково - практичних статей. - Харків: УкрДАЗТ, 2011 - №35 - С. 144-147

4. Бойко Д.І. Трансформація фінансових відносин на залізничному транспорті в умовах реструктуризації галузі /Д.І. Бойко, Н.Ю. Шинкарьова. -- Вісник економіки транспорту i промисловості: збірник науково-практичних статей, 2012 - №. 37 - C. $93-97$

5. Виханский, О. С. Стратегическое управление : учебник. / О. С. Виханский. - 2-е изд., перераб. и доп. - М. : Гардарики, 2005.$169 \mathrm{c}$.

6. Ансофф, И. Стратегическое управление / И. Ансофф ; пер. с англ. - М.: Экономика, 1989.- 358 с.
7. Шифрин, М.Б. Стратегический менеджмент : учеб. пособие / М.Б. Шифрин. - ЧПб: Питер, 2009.-240 с.

8. Дикань, В.Л. Стратегічне управління : навч.посіб./ В.Л.Дикань, В.О.Зубенко, О.В. Маковоз, І.В. Токмакова, О.В.Шраменко. - К: «Центр учбової літератури», 2013. -272c.

9. Экономическая стратегия фирмы: Учеб. пособие/ Под ред. А.П. Градова. 3-е изд., испр. - СПб.: Спец-Лит, 2012. - 414 с.

10. Морозов Т.Г. Прогнозирование и планирование в условиях рынка / Т.Г. Морозов, А.В. Пикулькин - М.: ЮНИТИ ДАНА, 2008. - 318c.

Рецензент д.е.н., професор УкрДУЗТ Зайцева І.Ю. Експерт редакційної колегї̈ к.е.н., доцент УкрДУЗТ Зубенко В.О.

УДК: 338.242

\title{
ПРИНЦИПИ ФУНКЦОНУВАННЯ СИСТЕМИ ЗАБЕЗПЕЧЕННЯ ЕКОНОМІЧНОЇ БЕЗПЕКИ ПІДПРИЕМСТВА
}

\author{
Павліченко В.М., кю.н., ст. викладач (ХІФ УДУФМТ)
}

В статті досліджено існуючі в літературі принципи функиіонування системи забезпечення економічної безпеки підприємства.

Нами удосконалено систему принципів за рахунок додання принципу пріоритетності податкової безпеки. Під иим принципом розумісмо забезпечення такого фінансовоекономічного стану підприємства, при якому з його боку вчасно сплачуються нараховані податки, а з боку виконавчих $і$ законодавчих органів забезпечується передбачений законом захист платника податків

Ключові слова: економічна безпека підприємства, система забезпечення економічної безпеки підприємства, принципи функціонування системи

\section{ПРИНЦИПЫ ФУНКЦИОНИРОВАНИЯ СИСТЕМЫ ОБЕСПЕЧЕНИЯ ЭКОНОМИЧЕСКОЙ БЕЗОПАСНОСТИ ПРЕДПРИЯТИЯ}

\author{
Павличенко В.Н., к.ю.н., ст. преподаватель (ХИФ УГУФМТ)
}

В статье исследованы существующие в литературе принципы функиионирования системы обеспечения экономической безопасности предприятия.

Нами усовершенствована система принципов за счет добавления принциипа приоритетности налоговой безопасности. Под этим принципом понимаем обеспечение такого финансово-экономического состояния предприятия, при котором с его стороны вовремя 